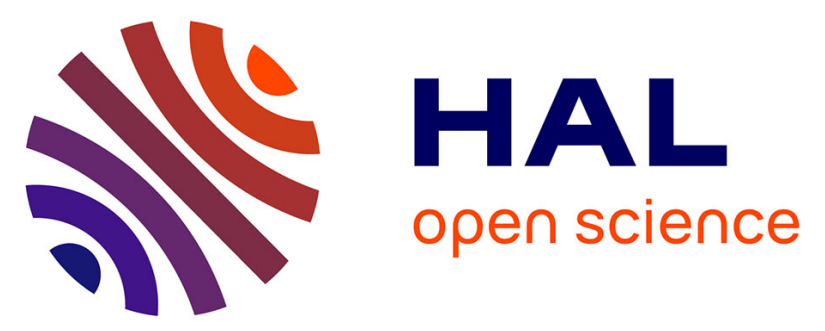

\title{
Time-temperature profiles of chilled ready-to-eat foods in school catering and probabilistic analysis of Listeria monocytogenes growth.
}

Philippe Rosset, Marie Cornu, Véronique Noël, Elisabeth Morelli, Gérard Poumeyrol

\section{To cite this version:}

Philippe Rosset, Marie Cornu, Véronique Noël, Elisabeth Morelli, Gérard Poumeyrol. Timetemperature profiles of chilled ready-to-eat foods in school catering and probabilistic analysis of Listeria monocytogenes growth.. International Journal of Food Microbiology, 2004, 96 (1), pp.49-59. 10.1016/j.ijfoodmicro.2004.03.008 . hal-00349238

\section{HAL Id: hal-00349238 \\ https://hal-anses.archives-ouvertes.fr/hal-00349238}

Submitted on 26 Dec 2008

HAL is a multi-disciplinary open access archive for the deposit and dissemination of scientific research documents, whether they are published or not. The documents may come from teaching and research institutions in France or abroad, or from public or private research centers.
L'archive ouverte pluridisciplinaire HAL, est destinée au dépôt et à la diffusion de documents scientifiques de niveau recherche, publiés ou non, émanant des établissements d'enseignement et de recherche français ou étrangers, des laboratoires publics ou privés. 


\title{
TIME-TEMPERATURE PROFLES OF CHIUED READY-TO-EAT FOODS IN SCHOOL CATERING AND PROBABIUSTIC ANALYSIS OF USTERIA MONOCYTOGENES GROWTH.
}

\author{
Philippe ROSSET ${ }^{*}$, Marie CORNU, Véronique NOËL, Elisabeth MORELLI, Gérard POUMEYROL
}

Agence Française de Sécurité Sanitaire des Aliments, LERAC, 22 rue Pierre Curie, BP 332, 94709 Maisons-Alfort cedex, F.

\begin{abstract}
The purpose of this study was to evaluate the chill chain in school catering by monitoring time/temperature profiles. Chilled ready-to-eat foods have been chosen as subject of this study because of their high risk due to a fabrication and a distribution without any thermal sanitation treatment. In order to integrate the effects of storage duration and storage temperature, a quantitative criterion, was calculated. To show the sanitary consequences of these data Listeria monocytogenes growth was predicted. The study of 5 centralized kitchens and 11 school lunch canteens demonstrated in general a satisfactory respect of the chill chain. However, the coincidence of extend storage duration (due to week-ends) and abuse temperature was observed and could lead to a significant microbial development.
\end{abstract}

Keywords: Food service; Chill chain; Risk factors; Predictive microbiology; Microbial risk assessment.

\section{INTRODUCTION}

Food safety is primordial in catering because of the high number of meals served every day. Foodborne outbreaks resulting from such mass catering facilities have been reported worldwide, notably in elementary and nursery schools. These school-lunch systems are of particular interest, as young children are at relatively high risk of developing serious complications from exposition to foodborne hazards.

The Japanese school lunch program constitutes an interesting case-study, intensively investigated by Michino and Otsuki (2000) and Lee et al. (2001). From 1981 through 1995, 533 outbreaks of food poisoning in Japan occurred at schools, and concerned over 100.000 people (Lee et al., 2001). Michino and Otsuki (2000) identified the causative factors for 62 outbreaks of foodborne illnesses that occurred in Japanese school lunch facilities, from 1987 to 1996. They were: storage of foods for an excessive period of time before serving (29/62), raw material contamination (29/62), inadequate cooking (21/62), cross contamination (21/62), and contamination by infected employees (9/62).

In France, almost 3.500 cases of foodborne illnesses linked to school lunch facilities were registered in 2000. Major factors contributing to foodborne outbreaks were attributed to: equipment contamination (55\%), raw material contamination (50\%), non-hygienic operations during preparation (46\%), abuse temperature of refrigerated storage (43\%), abuse duration of refrigerated storage (35\%) (Gallay, 2002). Non-respect of the chill chain (abuse temperature and/or abuse duration) appears then as an important reason for these foodborne outbreaks in school catering.

Centralized kitchens are mainly used in school catering. In these kitchens a very high number of meals (from a few hundreds to many thousands per day and per kitchen) are prepared and then delivered at short notice (1 to 3 days) to the canteens (quite often located in schools) where they are served to children. The meal fabrication can be laid on the use either of a warm chain - the meals are kept hot

\footnotetext{
* Corresponding author. Tel: +33 (0)1 497726 36; Fax: +33 (0)1 497738 88; E-mail: p.rosset@afssa.fr
} 
from cooking until eating - or of a chill chain - the cooked food is quickly cooled as soon as cooking ends and then kept cold, if necessary the food is rethermalized just before serving.

The purpose of this study was to evaluate the chill chain in school catering, by monitoring time/temperature profiles. Chilled ready-to-eat foods have been chosen as subject of this study because of their high risk due to a fabrication and a distribution without any thermal sanitation treatment.

In order to show the sanitary consequences of the time/temperature profiles - and more particularly the impact on potential growth of psychotrophic bacteria as Listeria monocytogenes - we integrated the effects of storage duration and storage temperature, through a quantitative criterion, the TTE ("timetemperature equivalent"). The quality of the chill chain was assessed using this criterion

Finally, to illustrate the potential use of these data for a quantitative microbial risks assessment, Listeria monocytogenes growth was predicted using standard predictive microbiology models (van Gerwen and Zwietering, 1998). Probabilistic modeling was conducted to incorporate variability (and uncertainty) of input data (time-temperature conditions and growth ability of Listeria monocytogenes) (Vose, 2000).

\section{MATERIALS AND METHODS}

\subsection{KITCHEN SAMPUNG}

Public centralized kitchens and school canteens in the suburbs of Paris were subject to a telephone survey to evaluate preparation of meals in the chill chain (see Table 1). They were divided among two groups according to the number of meals prepared per day. Two centralized kitchens ( $A$ and $E$ ) preparing under 5000 meals per day and three others ones ( $B, C$ and $D)$ preparing over 5000 meals per day were randomly selected. For each one, 2 (or 3) school canteens were selected according to the air temperature measured inside the cold cabinets (the best and the worst). If no significant difference among the air temperatures was noticed, the nearest and the farthest school canteens were selected. The study was conducted from November 2001 to June 2002.

\subsection{SEECTION OF FOOD PRODUCTS}

Chilled entrées, prepared with cooked or uncooked ingredients, were selected according to the methods (cutting, slicing, grating, mixing,...).Chilled entrées which did not undergo any transformation in the centralized kitchen, were eliminated (e.g. green salad with French dressing: the green salad packages were delivered unpacked to the school canteen, and then opened and mixed with some French dressing in the school canteen just before consumption by children).

\subsection{TEMPERATUREMEASUREMENT}

Food temperature was measured by inserting time temperature indicators (TTIs) (Proges Plus, Willems, France) into foods. Time and temperature were monitored every 3 minutes during all the stages of the fabrication and distribution: packaging, cold storage in centralized kitchen, transport to school canteens, and cold storage in canteens. Measuring started as soon as the last food transformation and/or mixing was completed. Measuring stopped at 12 A.M., at the day the chilled entrées were served to the children.

If possible foods were studied in the worst conditions (fail-safe choice): e.g. studied foods were transferred to cold storage only when the fabrication of this meal was completely finished. 


\subsection{TIMETEMPERATURE EQUIVALENT(TTE) CALCULATION}

The interest of time-temperature profiles was to show their sanitary impact on growth of pathogen bacteria. This modeling was based on simple and standard predictive microbiology models. The chosen primary model is the exponential growth, without lag phase nor stationary phase (fail-safe choice):

$$
N_{i+1}=N_{i} \exp \left(\mu_{i} t_{i}\right) \Leftrightarrow \ln \left(\frac{N_{i+1}}{N_{i}}\right)=\mu_{i} t_{i}
$$

where $\mathrm{N}_{\mathrm{i}}\left(\right.$ resp. $\left.\mathrm{N}_{\mathrm{i}+1}\right)$ is the number of microorganisms (CFU/g) at time $\mathrm{i}($ resp $\mathrm{i}+1), \mu_{\mathrm{i}}$ is the growth rate (day ${ }^{-1}$ ) assumed constant between $\mathrm{i}$ and $\mathrm{i}+1$, and $\mathrm{t}$ is the time duration (days) between $\mathrm{i}$ and $\mathrm{i}+1$.

For $\mathrm{n}$ successive steps, the total growth increment is:

$$
\ln \left(\frac{\mathrm{N}_{\mathrm{n}}}{\mathrm{N}_{0}}\right)=\sum_{\mathrm{i}} \mu_{\mathrm{i}} \mathrm{t}_{\mathrm{i}}
$$

where $N_{0}$ is the initial number of microorganisms (CFU/g) at time $0, N_{n}$ is the final number of microorganisms (CFU/g) after $n$ steps.

The chosen secondary model is the widely-used square-root model (Ratkowsky et al., 1983; Zwietering et al., 1996):

$\mu_{\mathrm{i}}=\mu_{\text {réf }}\left(\frac{\mathrm{T}_{\mathrm{i}}-\mathrm{T}_{\text {min }}}{\mathrm{T}_{\text {réf }}-\mathrm{T}_{\text {min }}}\right)^{2}=\frac{\mu_{\text {réf }}}{\left(\mathrm{T}_{\text {réf }}-\mathrm{T}_{\text {min }}\right)^{2}}\left(\mathrm{~T}_{\mathrm{i}}-\mathrm{T}_{\text {min }}\right)^{2}=\mathrm{b}^{2}\left(\mathrm{~T}_{\mathrm{i}}-\mathrm{T}_{\text {min }}\right)^{2}$

and $\mathrm{b}=\sqrt{\mu_{\text {réf }}} /\left(\mathrm{T}_{\text {réf }}-\mathrm{T}_{\text {min }}\right)$.

where $\mathrm{T}_{i}$ is the temperature $\left({ }^{\circ} \mathrm{C}\right)$ assumed constant between $\mathrm{i}$ and $\mathrm{i}+1, \mathrm{~T}_{\min }$ is the theoretical minimal temperature $\left({ }^{\circ} \mathrm{C}\right)$ of the species, and $\mu_{\text {ref }}$ is the growth rate (day $\left.{ }^{-1}\right)$ of the species in the food at temperature $T_{\text {ref. }}$.

From (2), and (3), the logarithmic microbial increment can be deduced:

$$
\ln \left(\frac{\mathrm{N}_{\mathrm{i}+1}}{\mathrm{~N}_{\mathrm{i}}}\right)=\mathrm{b}^{2} \mathrm{t}_{\mathrm{i}}\left(\mathrm{T}_{\mathrm{i}}-\mathrm{T}_{\min }\right)^{2} \Rightarrow \ln \left(\frac{\mathrm{N}_{\mathrm{n}}}{\mathrm{N} 0}\right)=\mathrm{b}^{2} \sum_{\mathrm{i}} \mathrm{t}_{\mathrm{i}}\left(\mathrm{T}_{\mathrm{i}}-\mathrm{T}_{\text {min }}\right)^{2}
$$

From equation 4, we defined a quantitative criterion, the TTE ("time-temperature equivalent"):

$$
\mathrm{TTE}=\sum_{\mathrm{i}} \mathrm{t}_{\mathrm{i}} \times\left(\mathrm{T}_{\mathrm{i}}-\mathrm{T}_{\min }\right)^{2}
$$

where $t_{i}$ is the time between 2 measurements (days), $\mathrm{T}_{i}$ is the temperature $\left({ }^{\circ} \mathrm{C}\right)$ measured at time $i$ and $\mathrm{T}_{\min }\left({ }^{\circ} \mathrm{C}\right)$ is the minimum growth temperature.

Thus, the TTE is linked to time, temperature and the studied bacterium, or more exactly its minimum growth temperature. The theoretical minimal temperature of Listeria monocytogenes was estimated at $2,7^{\circ} \mathrm{C}$ on the basis of 1865 growth curves by Augustin and Carlier (2000). Though uncertain and variable, this value was assumed to be fixed. Table 2 shows a few equivalent values between TTE and reference time-temperature couples. It is quite important to note that TTE does not depend on the type of food. A potential growth increment can be predicted as the product of a TTE and a parameter $b^{2}$, specific of the pathogen and the food product. 


\subsection{STATISTICAL ANALYSIS OF TTE}

Statistical analysis was conducted with Statgraphics Plus 5.1. (Manugistic ${ }^{\text {TM }}$, Maryland, USA) to evaluate the impact of each of six factors (centralized kitchens, school canteens, process, air temperatures, week-end, initial food temperature) on the TTE. The factor "School canteen" was embedded in the factor "centralized kitchen", with 2 or 3 canteens per kitchen: A1, A2, B1, B2, C1, C2, D1, D2, D3, E1, and E2. For each "process" parameter, 4 possibilities were defined: T, M, TM, and O. According to recipes, the process was able to follow 4 different actions: transformation $(T)$ as in cutting, slicing, crushing..., mixing (M), transformation and mixing (TM) or depackaging (D).

Median external air temperature was calculated every day with minimum and maximum air temperatures measured by the meteorological office (Météo France, Toulouse, France) in the kitchen surroundings. The reference day being the day the studied food was delivered to the school canteens. Averages and 95\% Bonferoni confidence intervals were calculated for every parameter.

\subsection{PREDICTION OF POTENTIAL LSTERIA MONOCYTOGENES GROWTH}

To predict the potential growth of Listeria monocytogenes, the next step in the model development was to take into account the impact of the food products. A literature survey was conducted to determine reference growth parameters of Listeria monocytogenes in chilled ready-to-eat entrees similar to those encountered in the present study. For each published challenge test, the maximal growth rate $\left(\mu_{\max }\right)$ was if necessary estimated by fitting an exponential model to the growth curve. The parameter $b^{2}$ was calculated on the basis of equation (2). When different growth curves were available for the same food product, the median of all calculated $b^{2}$ values was selected.

\subsection{PROBABIUSTIC SIMULATIONS}

A probabilistic analysis of potential Listeria monocytogenes growth was performed, taking into account "real world" variability of time-temperature profiles and food products. Measuring and sampling uncertainty were assumed to be negligible in comparison with variability. The potential growth increment of Listeria monocytogenes in a given food product along a given time-temperature profile is the product of the parameter $\mathrm{b}^{2}$, characterizing the food product, and the TTE, characterizing the time-temperature profile. Thus, a distribution of potential growth increments of Listeria monocytogenes could be obtained by multiplication of both distributions of $b^{2}$ and TTE. Note that Monte Carlo simulations were not necessary, thanks to the simplicity of the chosen model.

\section{RESULTS ANDDISCUSSION}

\subsection{TIME-TEMPERATURE PROFLES}

Were collected 287 time-temperature profiles (kitchen A : 62; kitchen B : 60; kitchen C : 54; kitchen D : 52 ; kitchen $E$ : 59 ). Figure 1 shows that each time-temperature profile was based on four successive periods with different durations: a period (a) with preparation and packaging in centralized kitchen, a period (b) with cold storage in centralized kitchen, a period (c) with delivering to school canteen, a period (d) with cold storage in school canteen. 
Period (a) consequences: As the temperature increases during this period, the cooling down period will last longer. This effect was according to initial food temperature.

Period (b) consequences: During this period (see period a) food was cooled and stored at a temperature lower than $4^{\circ} \mathrm{C}$. Generally the refrigerating system of centralized kitchens was correctly adjusted to obtain a temperature lower than $4^{\circ} \mathrm{C}$. Time-temperature profiles could be unsatisfactory when this period was reduced for the benefit of a longer period (d), e.g. when ready-to-eat foods were delivered to canteens on Friday, before the week-end, for being served on Monday, see period (d).

Period (c) consequences: Food was delivered on the day of serving. The refrigerating system of trucks was correctly adjusted to obtain a temperature of $<4^{\circ} \mathrm{C}$ and was on the whole time during delivery. Transfer time between lorry/cold cabinet in canteen was quite reduced, delivery time was limited (under $2 \mathrm{~h} 30)$.

Period (d) consequences: Generally this period was limited to a specific time, ready-to-eat foods were delivered on the day the food was to be served. Time-temperature profiles could be unsatisfactory when ready-to-eat foods were stored in incorrectly adjusted chill cabinet (sometimes temperature close to $6 / 8^{\circ} \mathrm{C}$ ) or during a longer period d, e.g. during week-end, see period (b).

\subsection{EVALUATION OF SANITARY CONSEQUENCES}

Time-temperature profiles were expressed by a single quantitative criterion, integrating both effects of temperature and duration on potential microbial growth: the time-temperature equivalent (TTE). Note that this TTE is a generalization of tTT, a criterion used by Nauta (in press), who assumed $T_{\text {min }}=0^{\circ} \mathrm{C}$ for the spoilage microbial population.

Calculations were in a first step applied to the specific case of Listeria monocytogenes, as its growth at low temperature and its potential presence in ready-to-eat chilled foods have been widely recognized (e.g. Farber et al., 1998; Aureli et al. 2000; Farber et al., 2000; Pingulkar et al., 2001).

Figure 2 presents the empirical histogram of the 287 calculated TTE. All of them were below 500 day. ${ }^{\circ} \mathrm{C}^{2}$, this limit corresponding to potential growth of Listeria monocytogenes after 267 hours (11.1 days) at $4^{\circ} \mathrm{C}$, or 105 hours $\left(4,4\right.$ days) at $8^{\circ} \mathrm{C}$, or 56 hours (2.3 days) at $12^{\circ} \mathrm{C}$ (see Table 2$)$. The majority of TTE (158 among 287, 55\%) was under 100 day. ${ }^{\circ} \mathrm{C}^{2}$, this limit corresponding to potential growth of Listeria monocytogenes after 53 hours at $4^{\circ} \mathrm{C}$, or 21 hours at $8^{\circ} \mathrm{C}$, or 11 hours at $12^{\circ} \mathrm{C}$. Note that those TTE can not be converted into growth increments without taking into account the behavior of the microorganism in the food product (namely through the parameter $b^{2}$ ).

To determine conditions having the biggest effect upon TTE (and in fact upon the quality of the chilled chain), a one-way analysis of variance was performed. Significant factors were: the centralized kitchen $(p<0.0001)$, the school canteen $(p=0.0001)$, and the presence or absence of a week-end between preparation and consumption $(p<0.0001)$. The between-kitchen and within-kitchen between-school variabilities are demonstrated in table 3.

No significant differences were shown for processes $(p=0.25)$, meteorological conditions $(p=0.25)$ and initial food temperature $(p=0.25)$. It was also demonstrated that neither the season nor the recipe have a significant effect on TTE (data not shown).

Tessi et al. (2002) highlighted the importance to cool boiled ingredients (rice, cereals, vegetables...) before their integration into mixed salads. In absence of this cooling step, they observed that salads were sometimes kept at temperatures between 28 and $32^{\circ} \mathrm{C}$, enabling both spore germination and fast 
microbial growth. In the surveyed kitchens, this cooling step was satisfactory as the initial temperature of salads at the time of mixing was always below $22^{\circ} \mathrm{C}(75 \%$ studied foods had an initial temperature between $6^{\circ} \mathrm{C}$ and $11^{\circ} \mathrm{C}$, with an average of $8^{\circ} \mathrm{C}$ ). The absence of significant effect of initial temperature on the TTE confirms that this potential risk factor was well controlled.

The highest values of TTE were explained by a combination of long storage time (during week-end, preparation on Friday and service on Monday) and high storage temperatures (in school canteens chilled cabinets incorrectly adjusted). So we can consider that food storage during the week-end was better managed in centralized kitchen than in school canteens.

The integration of time and temperature effect in a single quantitative criterion appears to us as a useful way to assess the quality of the chill chain, especially since miniaturized, simple and inexpensive temperature captors have appeared. This general field of temperature function integration and timetemperature integration was at the basis of early works in predictive microbiology and is still in great development (Olley and Ratkowsky, 1973; Daud et al., 1978; Gill et al., 1991; Dickson et al., 1992; Snyder, 1998; Giannakourou et al., 2001).

\subsection{PROBABIUSTIC ANALYSIS OF POTENTIAL LSTERIA MONOCYTOGENES GROWTH.}

Reference growth rates of Listeria monocytogenes in different ready-to eat chilled foods, similar to those of the present study, were calculated from literature, see Table 4 . Thus, 16 values of $b^{2}$ were obtained, and they were considered as equiprobable. This empirical distribution of $\mathrm{b}^{2}$ was taken as representative of the variability (and uncertainty) of Listeria monocytogenes growth ability in these different foods. Combining distributions of TTE and $b^{2}, 16 \times 287=4592$ potential growth increments were obtained. Their distribution (Figure 3)characterized the variability (and uncertainty) of Listeria monocytogenes growth increments in these different foods along with these different time-temperature courses.

For most combinations (70\%), the growth increment would be less than $0.69 \ln (\mathrm{CFU} / \mathrm{g})$ or $0.3 \log _{10}(\mathrm{CFU} / \mathrm{g})$, i.e. the growth would be either null (case of carrots and tomatoes) or negligible (less than one doubling of the population). Only $4 \%$ of combinations lead to more than 3 doublings, i.e. a multiplication of the microbial population by more than 8 . The highest growth predicted, corresponding to the worst time-temperature profile and the fastest growth (in chicken salad), would lead to a growth increment of $8 \ln (\mathrm{CFU} / \mathrm{g})$ or $3.5 \log _{10}(\mathrm{CFU} / \mathrm{g})$, i.e. a multiplication of the microbial population by 3.000 .

This probabilistic analysis illustrates the application of field data to the development of quantitative predictions, taking into account variability (and uncertainty) of the food service industry. A previous study concerned the warm chain and the potential growth of Clostridium botulinum (Fazil et al., 2002) and, to our best knowledge, our study is the first one applied to the chill chain, even if numerous data are still lacking to fully characterize both uncertainties and variabilities on each input factor for a complete microbial risk assessment. 


\section{CONCLUSION}

Refrigerated storage of ready-to-eat foods has often been targeted as a potential risk factor for development of microbial hazards, and foodborne illnesses. The present survey of 5 centralized kitchens and 11 school lunch canteens demonstrated in general a satisfactory respect of the chill chain. However, the coincidence of extend storage duration (due to week-ends) and abuse of refrigeration temperature was observed and could lead to a significant microbial development. A modeling approach, based on predictive microbiology and probabilistic simulations, was proposed for a simple quantitative assessment of the quality of the chill-chain, and the associated microbial risks. This preliminary approach should then be included in a whole microbial risk assessment.

\section{Acknowledgements}

The authors are especially grateful to the catering managers who participated to this project. The authors wish also to thank Mss Séverine CAILLER, Aurianne LESEUR and Mr Frédéric HERVE for their technical participation, and Ms Denise CLEMENT DE SUZA for her translation help.

\section{REFERENCES}

Augustin, J.C.,Carlier, V., 2000. Modelling the growth rate of Listeria monocytogenes with a multiplicative type model including interactions between environmental factors. Int. J. Food Microbiol. $56,53-70$.

Aureli, P., Fiorucci, G.C., Caroli, D., Marchiaro, G., Novara, O., Leone, L., Salmaso, S., 2000. An outbreak of febrile gastroenteritis associated with corn contaminated by Listeria monocytogenes. $\mathrm{N}$. Engl. J. Med. 342, 1236-1241.

Berrang, M.E., Brackett, R.E., Beuchat, L.R. ,1989. Growth of Listeria monocytogenes on fresh vegetables stored under controlled atmosphere. J. Food Prot. 52,702-705.

Beuchat, L.R., Brackett, R.E., 1990. Survival and growth of Listeria monocytogenes on lettuce as influenced by shredding, chlorine treatment, modified atmosphere packaging and temperature. J. Food Sci. 55, 755-758, 870.

Carlin, F., Nguyen-The, C., 1994. Fate of Listeria monocytogenes on four types of minimally processed green salads. Lett. Appl. Microbiol. 18, 222-226.

Carlin, F., Nguyen-The, C., Morris, C.E., 1996. Influence of background microflora on Listeria monocytogenes on minimally processed fresh broad-leaved endive (Chichorium endivia var. latifolia). J. Food Prot. 59, 698-703.

Daud H.B., McMeekin, T.A., Olley J., 1978. Temperature function integration and the development and metabolism of poultry spoilage bacteria. Appl. Environ. Microbiol. 36, 650-654.Delaquis, S., Stewart, S.,

Delaquis, S., Stewart, S., Cazaux, S.Toivonen, P., 2002. Survival and growth of Listeria monocytogenes and Escherichia coli $0157: \mathrm{H} 7$ in ready-to-eat iceberg lettuce washed in warm chlorinated water. J. Food Prot. 65, 459-464. 
Dickson, J.S., Siragusa, G.R., Wray, J.E., 1992. Predicting the growth of Salmonella typhimurium on beef by using the temperature function integration technique. Appl. Environ. Microbiol. 58, 3482-3487.

Erickson, J.P., McKenna, D.N., Woodruff, M. A.Bloom, J.S., 1993. Fate of Salmonella spp., Listeria monocytogenes, and indigenous spoilage microorganisms in home-style salads prepared with commercial real mayonnaise or reduced calorie mayonnaise dressings. J. Food Prot. 56, 1015-1021.

Farber, J.M., Wang, S.L., Cai, Y., Zhang, S., 1998. Changes in populations of Listeria monocytogenes inoculated on packaged fresh-cut vegetables. J. Food Prot. 61, 192-195.

Farber, J.M., Daley, E.M., MacKie, M.T., Limerick, B., 2000. A small outbreak of listeriosis potentially linked to the consumption of imitation crab meat. Lett. Appl. Microbiol. 31, 100-104.

Fazil, A..M., Ross, T., Paoli, G., Vanderlinde, P., Desmarchelier, P., Lammerding, A.M., 2002. A probabilistic analysis of Clostridium perfringens growth during food service operations. Int. J. Food Microbiol. 73, 315-329.

Gallay, A., 2002. Toxines microbiennes dans les toxi-infections alimentaires collectives déclarées en France. Congress of the French Society of Microbiology. November 2002, Paris.

Giannakourou, M.C., Koutsoumanis, K., Nychas, G.J., Taoukis, P.S., 2001. Development and assessment of an intelligent shelf life decision system for quality optimization of the food chill chain. J. Food Prot. 64, 1051-1057.

Gill, C.O., Jones, S.D.M., Tong, A.K.W, 1991. Application of a temperature function integration technique to assess the hygienic adequacy of a process for spray chilling beef carcasses. J. Food Prot. $54,731-736$

Glass, K.A., Doyle, M.P., 1989. Fate of Listeria monocytogenes in processed meat products during refrigerated storage. Appl. Environ. Microbiol., 55, 1565-1569.

Lee, W.C., Lee, M.J., Kim, J.S., Park, S.Y., 2001. Foodborne illness outbreaks in Korea and Japan studied retrospectively. J. Food Prot. 64, 899-902.

McKellar, R.C., Moir, R., Kalab, M., 1994. Factors influencing the survival and growth of Listeria monocytogenes on the surface of Canadian retail wieners. J. Food Prot. 57, 387-392.

Michino, H., Otsuki, K., 2000. Risk factors in causing outbreaks of food-borne illness originating in schoollunch facilities in Japan. J. Vet. Med. Sci. 62, 557-560.

Nauta, M., Litman, S., Barker, G.C., Carlin, F., in press. A retail and consumer phase model for exposure assessment of Bacillus cereus. Int. J. Food Microbiol. in press.

Nguyen The, C., Lund, B.M., 1991. The lethal effect of carrot in Listeria species. J. Appl. Bacteriol. 70, 479-488.

Nguyen The, C., Halna du Fretay, B., Abreu da Silva, A., 1996. The microbiology of mixed salad containing raw and cooked ingredients without dressing. Int. J. Food Sci. Technol. 31, 481-487. 
Olley, J, Ratkowsky, D.A. 1973. The role of temperature function integration in monitoring of fish spoilage. Food Technol. NZ. 8, 13-17.

Papageorgiou, D.K., Marth, E.H. 1989. Fate of Listeria monocytogenes during the manufacture and ripening of feta cheese. J. Food Prot. 52, 82-87.

Pingulkar, K., Kamat, A.Bongirwar, D., 2001. Microbiological quality of fresh leafy vegetables, salad components and ready-to-eat salads: an evidence of inhibition of Listeria monocytogenes in tomatoes. Int J. Food Sci. Nutr. 52, 15-23.

Ratkowsky, D.A., Lowry, R.K., McMeekin, T.A., Stokes, A.N., Chandler, R.E., 1983. Model for bacterial culture growth rate throughout the entire biokinetic temperature range. J. Bacteriol. 154, 1222-1226.

Rosenow, E.M., Marth, E.H., 1987. Growth of Listeria monocytogenes in skim, whole and chocolate milk, and in whipping cream during incubation at 4, 8,13, 21 and $35^{\circ} \mathrm{C}$. J. Food Prot. 50:452-459.

Sizmur, K., Walker C. W., 1988. Listeria in prepacked salads. The Lancet 331, 1167.

Snyder, O.P., 1998. Updated guidelines for use of time and temperature specifications for holding and storing food in retail food operations. Dairy Food Environ. Sanit. 18, 574-579.

Stecchini, M.L., Aquili, V., Sarais, I., 1995. Behavior of Listeria monocytogenes in mozzarella cheese in the presence of Lactococcus lactis. Int. J. Food Microbiol. 25, 301-310.

Steinbruegge, E.G., Maxcy, R.B., Liewen, M.B., 1988. Fate of Listeria monocytogenes on ready to serve lettuce. J. Food Prot. 51, 596-599.

Thomas, C., Prior, O., O'Beirne, D., 1999. Survival and growth of Listeria species in a model ready-touse vegetable product containing raw and cooked ingredients as affected by storage temperature and acidification. Int. J. Food Sci. Technol. 34, 317-324.

Thomas, C., O'Beirne, D., 2000. Evaluation of the impact of short-term temperature abuse on the microbiology and shelf life of a model ready-to-use vegetable combination product. Int. J. Food Microbiol. 59, 47-57.

van Gerwen, S.J., Zwietering, M.H., 1998. Growth and inactivation models to be used in quantitative risk assessments. J. Food Prot. 61, 1541-1549.

Vose, D., 2000. Risk Analysis, a quantitative guide, $2^{\text {nd }}$ ed. Wiley and Sons, Chichester, pp. 418.

Wederquist, H.J., Sofos, J.N., Schmidt, G.R., 1994. Listeria monocytogenes inhibition in refrigerated vacuum packed turkey bologna by chemical additives. J. Food Sci. 59, 498-500, 516.

Zwietering, M.H., de Wit, J.C., Notermans, S., 1996. Application of predictive microbiology to estimate the number of Bacillus cereus in pasteurised milk at the point of consumption. Int. J. Food Microbiol. 30, 55-70. 
Figure 1: Example of a typical time-temperature profile, with four successive periods. a: preparation and packaging in the centralized kitchen; b: refrigerated storage in the centralized kitchen; c: transfer to school canteen; d: refrigerated storage in the school canteen

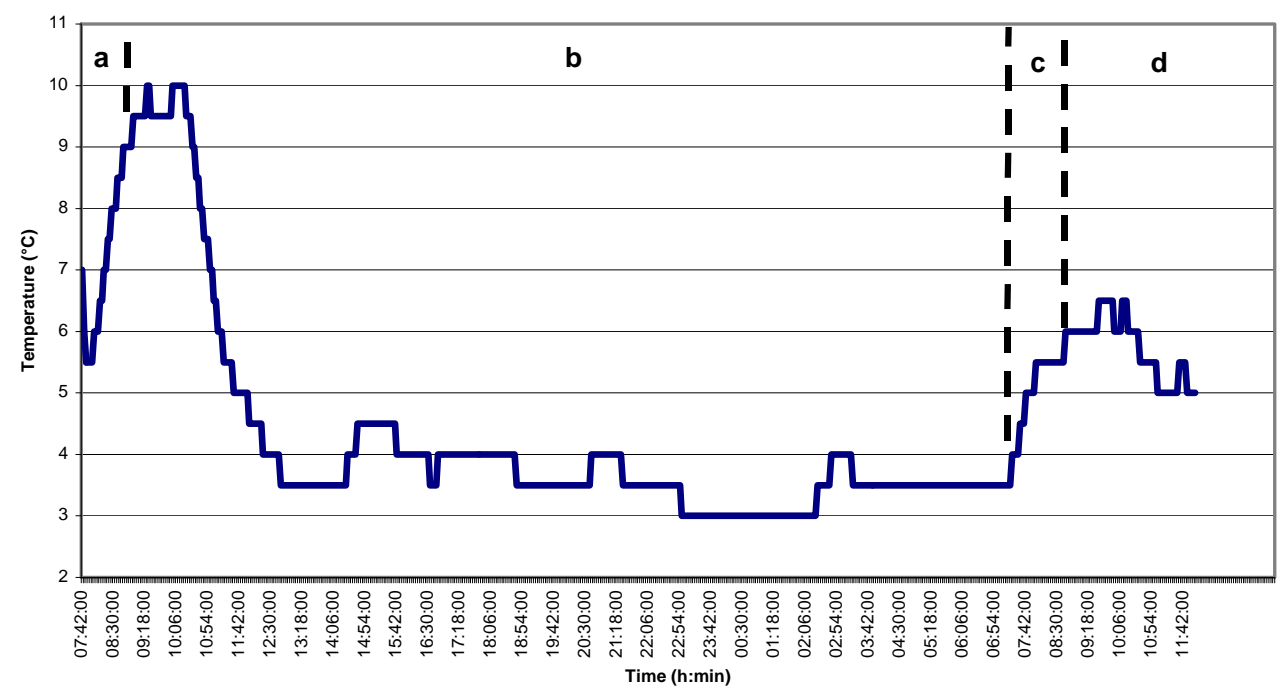

Figure 2: Empirical distribution of 287 time-temperature equivalents (day. ${ }^{\circ} \mathrm{C}^{2}$ ). Reading key : $27 \%$ of time-temperature profiles are characterized by a TTE between 75 and 100 day. ${ }^{\circ} \mathrm{C}^{2}$ and would allow a potential growth of Listeria moncocytogenes equivalent to $40-53$ hours at $4^{\circ} \mathrm{C}, 16-21$ hours at $8^{\circ} \mathrm{C}$ or 811 hours at $12^{\circ} \mathrm{C}$.

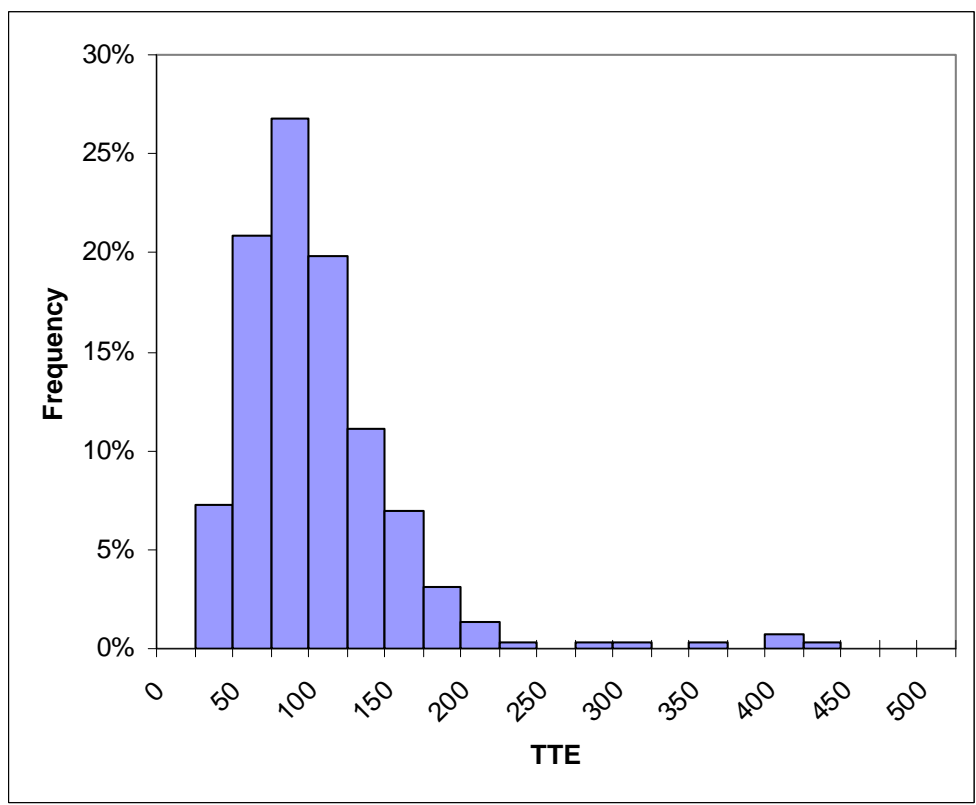


Figure 3: Simulated distribution of $287 \times 16=4592$ predicted growth increments. Reading key : $20 \%$ of combinations are characterized by a growth increment comprised between 0.69 and 1.38 In (UFC/g), and would allow a potential growth of Listeria moncocytogenes between one and two doublings.

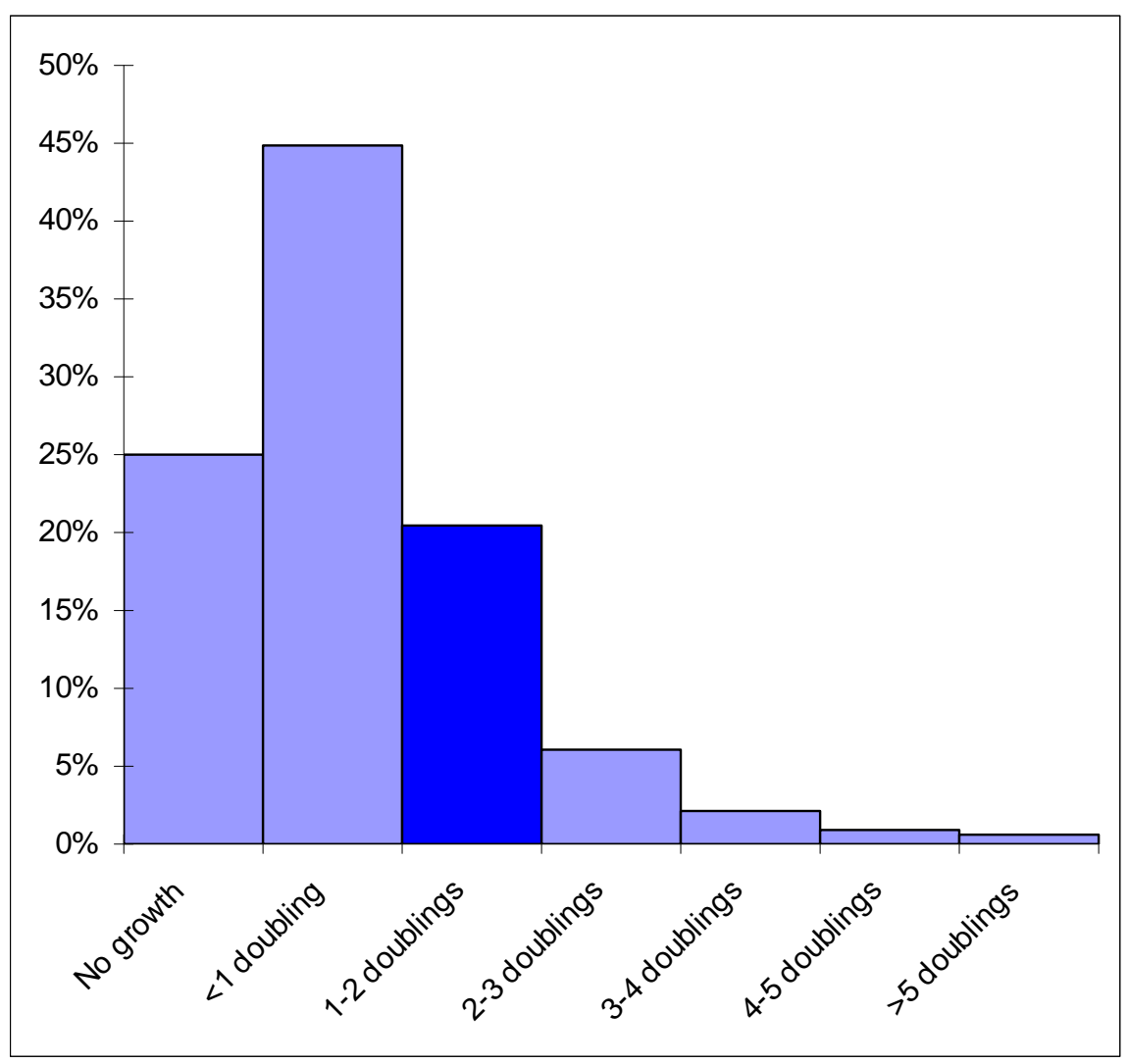


Table 1: Centralized kitchens repartition

\begin{tabular}{l|c|c}
\hline & All types of chain & Chill chain \\
\hline Number of districts of the studied area & 123 & \\
Number of centralized school kitchen & 77 & $36(47 \%)$ \\
Number of centralized school kitchen making during the school & & \\
period: & 46 & $15(33 \%)$ \\
$<3000$ meals per day & 21 & $12(57 \%)$ \\
$3000<n<5000$ meals per day & 10 & $9(90 \%)$ \\
$>5000$ meal per day & 53 & $16(30 \%)$ \\
Number of public centralized school kitchen & 24 & $18(75 \%)$ \\
Number of private centralized school kitchen & & \\
Number of school restaurants per centralized kitchen: & 46 & $15(33 \%)$ \\
$<20$ & 27 & $17(63 \%)$ \\
$20<n<50$ & 4 & $4(100 \%)$ \\
$>50$ &
\end{tabular}

Table 2 : TTE and reference time-temperature couples for $\mathrm{L}$. monocytogenes $\left(\mathrm{Tmin}=-2.7^{\circ} \mathrm{C}\right.$ )

\begin{tabular}{cccc}
\hline $\begin{array}{c}\text { TTE } \\
\left.\text { (day. }{ }^{\circ} \mathrm{C}^{2}\right)\end{array}$ & $\begin{array}{c}\text { Time at } 4^{\circ} \mathrm{C} \\
(\mathrm{h})\end{array}$ & $\begin{array}{c}\text { Time at } 8^{\circ} \mathrm{C} \\
(\mathrm{h})\end{array}$ & $\begin{array}{c}\text { Time at } 12^{\circ} \mathrm{C} \\
(\mathrm{h})\end{array}$ \\
\hline 50 & 27 & 10 & 6 \\
75 & 40 & 16 & 8 \\
100 & 53 & 21 & 11 \\
200 & 107 & 42 & 22 \\
300 & 160 & 63 & 33 \\
500 & 267 & 105 & 56 \\
\hline
\end{tabular}

Reading key: it is assumed that the potential growth of Listeria monocytogenes (or any microbial species with a minimal temperature of $-2.7^{\circ} \mathrm{C}$ ) in any food product would be equivalent during 107 hours ( 4.5 days) at $4^{\circ} \mathrm{C}, 42$ hours at $8^{\circ} \mathrm{C}, 22$ hours at $4^{\circ} \mathrm{C}$ or any time-temperature profile with a TTE of 200.

Table 3 : Average, minimal, and maximal TTE per kitchen (a) or per canteen (b)

a)

\begin{tabular}{l|cccccc}
\hline \multicolumn{1}{c|}{ TTE } & \multicolumn{5}{c}{ CENTRALIZED KITCHEN } \\
$\left(\right.$ day. ${ }^{\circ} \mathrm{C}^{2}$ ) & $\mathrm{A}$ & $\mathrm{B}$ & $\mathrm{C}$ & $\mathrm{D}$ & $\mathrm{E}$ & Total \\
\hline Average & 127 & 89 & 130 & 104 & 78 & 105 \\
Max & 374 & 205 & 440 & 162 & 222 & 440 \\
Mini & 60 & 40 & 51 & 27 & 36 & 27 \\
\hline
\end{tabular}

b)

\begin{tabular}{l|ccccccccccc}
\hline \multicolumn{1}{c|}{ TTE } & \multicolumn{1}{c}{ TT } & \multicolumn{1}{c}{ SCHOOL CANTEEN } \\
$\left(\right.$ day. ${ }^{\circ} \mathrm{C}^{2}$ ) & A1 & A2 & B3 & B4 & C5 & C6 & D7 & D8 & D9 & E10 & E11 \\
\hline Average & 141 & 112 & 86 & 92 & 108 & 150 & 100 & 97 & 108 & 64 & 92 \\
Max & 374 & 172 & 174 & 205 & 295 & 440 & 156 & 131 & 162 & 118 & 222 \\
Mini & 78 & 60 & 53 & 40 & 55 & 51 & 27 & 39 & 43 & 36 & 45 \\
\hline
\end{tabular}


Table 4: Reference growth curves of $L$. monocytogenes in different ready-to-eat food products

\begin{tabular}{|c|c|c|c|c|}
\hline Food product & Source & $\mathrm{T}\left({ }^{\circ} \mathrm{C}\right)$ & $\mathrm{n}^{*}$ & $b^{2}$ \\
\hline Chicken salad & Erickson et al., 1993 & $4-13$ & 4 & 0.018 \\
\hline Canned sweet corn & $\begin{array}{l}\text { Thomas and O'Beirne, 2001; } \\
\text { Thomas et al., 1999; N'Guyen-The } \\
\text { et al., 1999, Carlin et al., } 2001\end{array}$ & $3-12$ & 12 & 0.015 \\
\hline Cream $^{* *}$ & Rosenow and Marth, 1987 & $4-8$ & 2 & 0.010 \\
\hline Frankfurters & $\begin{array}{l}\text { Glass and Doyle, 1989; McKellar et } \\
\text { al., 1994, Wederquist et al., } 1994\end{array}$ & $4-5$ & 3 & 0.007 \\
\hline Mozarella & Stecchini et al., 1995 & 5 & 1 & 0.007 \\
\hline Coleslaw & Farber et al., 1998 & 10 & 1 & 0.007 \\
\hline Caesar salad & Farber et al., 1998 & 10 & 1 & 0.006 \\
\hline Cauliflower & Berrang et al., 1989 & 15 & 1 & 0.006 \\
\hline Mixed salad & Sizmur and Waker, 1988 & 4 & 1 & 0.004 \\
\hline $\begin{array}{l}\text { Endive (broad-, curly-, } \\
\text { and/or red-leaved) }\end{array}$ & $\begin{array}{l}\text { Carlin et al., 1996; Carlin and } \\
\text { N'Guyen-The, 1994, N'Guyen-The } \\
\text { et al., } 1996\end{array}$ & $3-10$ & 6 & 0.003 \\
\hline Raw bean sprouts & Thomas and O'Beirne, 2001 & $3-12$ & 7 & 0.002 \\
\hline Cut lettuce & $\begin{array}{l}\text { Steinbrugge et al., 1988; Beuchat } \\
\text { and Bracket, 1990; Carlin and } \\
\text { n'Guyen-The, 1994, Thomas et al., } \\
1999 \text {; Delaquis et al., } 2002\end{array}$ & $5-12$ & 7 & 0.002 \\
\hline Feta & Papageorgiou and Marth & 4 & No growth & $0^{* * *}$ \\
\hline Pasta salad & Erickson et al., 1993 & $4-13$ & No growth & 0 \\
\hline Carrots & Nguyen The and Lund, 1991 & 8 & No growth & 0 \\
\hline Tomatoes & Pingulkar et al., 2001 & $8-10$ & No growth & 0 \\
\hline
\end{tabular}

${ }^{*} n$ is the number of growth curves published for each food product. If $n>1, b^{2}$ was estimated for each growth curve, and the median was selected.

${ }^{* *}$ Cream is used as a dressing for cucumber salad.

${ }^{* * *}$ A null value of $b^{2}$ indicates either no-growth (survival) or inactivation. 